\title{
The Sizes, Growth and Reproduction of Arrow Worms (Chaetognatha) in Light of the Gill-Oxygen Limitation Theory (GOLT)
}

\author{
Daniel Pauly ${ }^{1}$, Cui Liang ${ }^{2,3}$, Weiwei Xian ${ }^{2,3}$, Elaine Chu ${ }^{1}$ and Nicolas Bailly ${ }^{1,4, *}$ \\ 1 Sea Around Us, Institute for the Oceans and Fisheries, University of British Columbia, \\ Vancouver, BC V6T 1Z4, Canada; d.pauly@oceans.ubc.ca (D.P.); e.chu@oceans.ubc.ca (E.C.) \\ 2 CAS Key Laboratory of Marine Ecology and Environmental Sciences, Institute of Oceanology, Chinese \\ Academy of Sciences, Qingdao 266071, China; liangc@qdio.ac.cn (C.L.); wwxian@qdio.ac.cn (W.X.) \\ 3 Laboratory for Marine Ecology and Environmental Science, Qingdao National Laboratory for Marine Science \\ and Technology, Chinese Academy of Sciences, Qingdao 266237, China \\ 4 UBC Fish Collection, Beaty Biodiversity Museum, University of British Columbia, \\ Vancouver, BC V6T 1Z4, Canada \\ * Correspondence: n.bailly@q-quatics.org
}

Citation: Pauly, D.; Liang, C.; Xian, W.; Chu, E.; Bailly, N. The Sizes,

Growth and Reproduction of Arrow Worms (Chaetognatha) in Light of the Gill-Oxygen Limitation Theory (GOLT). J. Mar. Sci. Eng. 2021, 9, 1397. https://doi.org/10.3390/jmse9121397

Academic Editor:

Dariusz Kucharczyk

Received: 27 October 2021

Accepted: 26 November 2021

Published: 7 December 2021

Publisher's Note: MDPI stays neutral with regard to jurisdictional claims in published maps and institutional affiliations.

Copyright: (c) 2021 by the authors. Licensee MDPI, Basel, Switzerland. This article is an open access article distributed under the terms and conditions of the Creative Commons Attribution (CC BY) license (https:// creativecommons.org/licenses/by/ $4.0 /)$.

\begin{abstract}
The Chaetognatha are a marine invertebrate phylum including 132 extant, carnivorous species in nine families and two orders, but with unclear protostomian affinities in the animal kingdom. We document the gradual recognition of the distinctiveness of chaetognaths by early taxonomists, with some emphasis on the often-overlooked studies by Chinese marine biologists. The carnivorous arrow worms are understudied relative to their importance in the marine zooplankton, where they rank second in abundance after the herbivorous copepods. Although arrow worms lack gills or other dedicated respiratory organs, we show that the Gill-Oxygen Limitation Theory (GOLT) can be used to explain how temperature and respiration affect their growth and related life-history traits. Notably, we present a reappraisal of evidence for size-temperature relationships between and within chaetognath species, and for the relationship between their temperature-mediated oxygen demand and their growth patterns. Von Bertalanffy weight growth curves of Ferosagitta hispida (family: Sagittidae) based on earlier aquarium experiments by various authors are presented, which suggest (a) a good fit and (b) that the life span of chaetognaths is much lower than suggested by the authors of several published growth curves drawn onto length-frequency samples from the wild. In addition, we show that chaetognaths attain first maturity at a fraction of the maximum length they can attain that is similar to the corresponding fraction in fishes. Overall, we suggest that the manner in which the oxygen they require enters the body of small marine invertebrates, although often neglected, is a crucial aspect of their biology. In addition, based on our result that arrow worms conform to the GOLT, we suggest that this theory may provide the theoretical framework for the study of growth in the other water-breathing ectotherms lacking gills.
\end{abstract}

Keywords: von Bertalanffy; respiration; morphometrics; growth; size-temperature relationships

\section{Introduction}

The Chaetognatha (i.e., "bristle jaws"), or arrow worms (Figure 1), belong to a marine invertebrate phylum with unclear protostomian affinities in the animal kingdom, and are spread through all oceans from the surface down to $5000 \mathrm{~m}$, with a $6000 \mathrm{~m}$ record to be confirmed. Of the 132 extant species currently recognized [1], 58\% are pelagic, and $42 \%$ benthopelagic or benthic [2]. In the marine zooplankton, their biomass is about 1/3 that of copepods globally, and over $1 / 5$ of the total zooplankton in the North Atlantic [3]. The maximum sizes of chaetognaths range over two orders of magnitude, from $1.3 \mathrm{~mm}$ in Spadella boucheri [4] to 105 $\mathrm{mm}$ in Pseudosagitta gazellae [5,6]. Arrow worms are carnivorous, feeding preferentially on copepods, but also on other small invertebrates and fish larvae [7-9]. While a few species 
are reported to consume bacteria and particulate or dissolved matter, e.g., in the nepheloid layer and polar areas [10-12], as an adaptative response to the scarcity of prey, more studies are required on more species to generalize these food sources for the entire phylum. In turn, chaetognaths contribute substantially to the zooplankton consumed by commercially exploited fish [13].

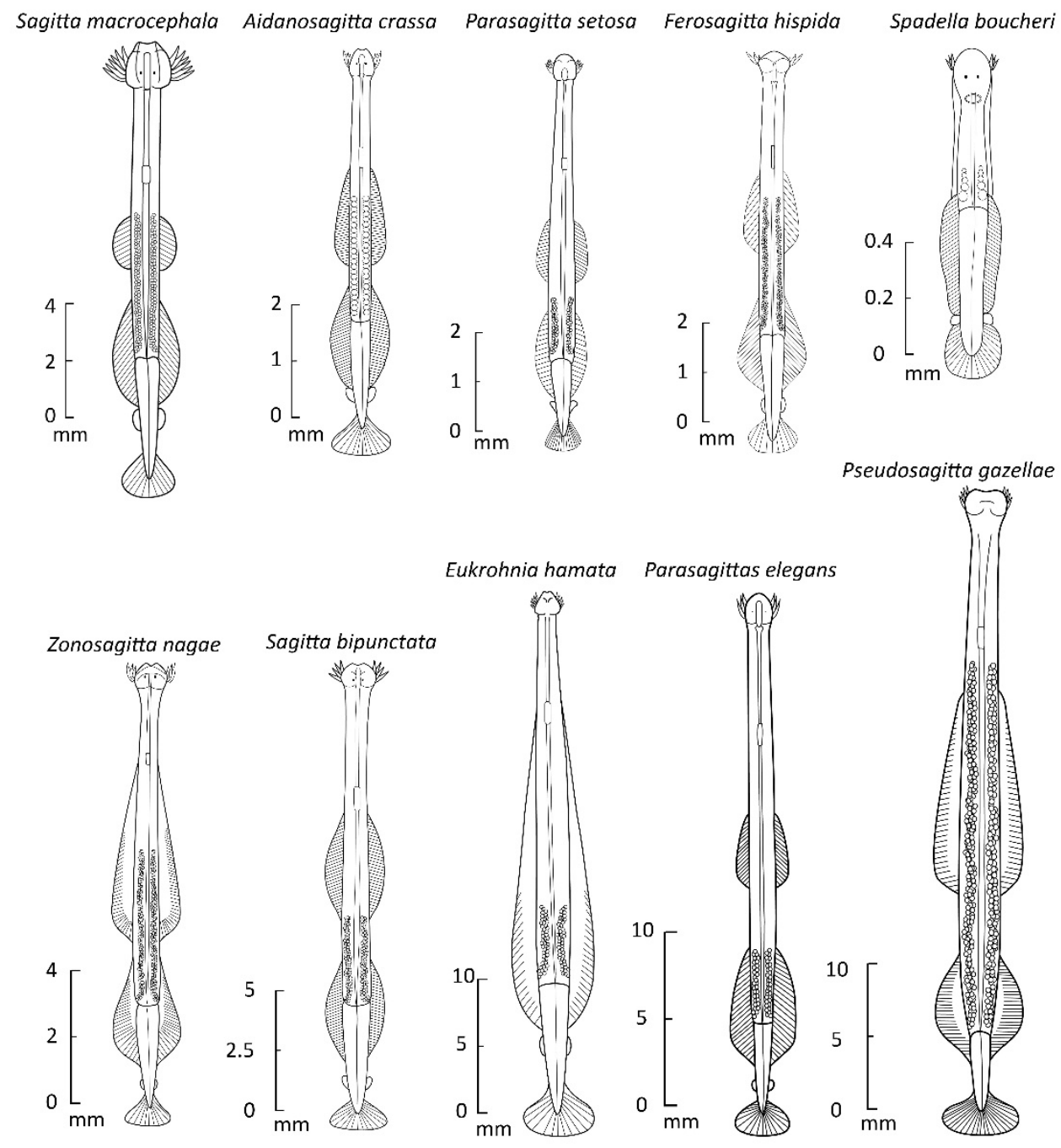

Figure 1. Illustrating the uniformity of body shapes with the phylum Chaetognatha, which includes species ranging in maximum body length from $1.3 \mathrm{~mm}$ in Spadella boucheri to $105 \mathrm{~mm}$ in Pseudosagitta gazellae (redrawn by E. Chu from multiple sources).

Here, we document, based on a brief review of the zoological literature spanning the years 1771 to 1911, the gradual recognition of the distinctiveness of chaetognaths by early taxonomists, and the establishment in 1965 of their currently accepted classification. Then, we briefly focus on the often-overlooked studies by Chinese scientists. This sets the stage for a reappraisal of the knowledge about the growth and reproduction of chaetognaths as related to oxygen consumption, as outlined in the Gill-Oxygen Limitation Theory (GOLT; [14-16]), which was developed to explain the growth of gilled marine organisms. Although chaetognaths lack gills [17], the GOLT is used here to explain thus-far neglected aspects of the biology of arrow worms, in particular their growth and reproduction, and their relationships to temperature.

The GOLT is based on the observation that water-breathing ectotherms (WBE) obtain their supply of oxygen through a surface (that of their gills, or through another surface in gill-less WBE), but that this surface cannot, for geometric reasons, keep up with the growth 
of the body whose mass generates the oxygen demand. Thus, as WBE grow, their oxygen supply per unit weight must decline, which impacts their growth and reproduction, both of which are oxygen-dependent [16].

When water-breathing ectotherms (WBE) have hard parts, such as bones, otoliths and scales in fish, or statoliths in squids, the age at different sizes can be estimated by counting annual rings in long-lived fish exposed to marked summer-winter differences in the temperature of their habitats, or daily rings in otoliths or statoliths [15]. Unfortunately, arrow worms do not have statoliths [18]. Thus, the growth of chaetognaths must be inferred from specimens grown in the laboratory, or from the analysis of length-frequency (L/F) data sampled in the wild. However, there are many misunderstandings about the correct way to infer growth from L/F data. Many authors place great emphasis on identifying the peaks of their various L/F samples, assumed to represent cohorts. On the other hand, they place less emphasis on the criteria they (should) use for linking the peaks of successive L/F samples with each other, although this is the very process that generates growth increments upon which growth curves can be based [19].

Increased temperatures, by increasing Brownian motion and hence the shocks between water molecules and proteins, reduce the half-life of the proteins in the bodies of WBE. The denatured proteins must be resynthesized, thus increasing $\mathrm{O}_{2}$ consumption. When the water around WBE becomes warmer, their asymptotic length and weight should thus decline (as per the interpretation of Equation (3) below in Material and Methods). Thus, with regard to growth, the applicability of the GOLT to arrow worms can be tested via three hypotheses:

1. Species living in colder water will tend to be larger than those living in warmer temperatures, other factors being equal.

2. Within different populations of the same species, maximum size and mean size at first maturity should decline with temperature.

3. The growth of chaetognaths should conform to the VBGF.

In the absence of gills, arrow worms breathe through their integument, i.e., body walls [20]. Thus, their respiratory surface area is small and cannot be very thin because it also functions as part of their hydrostatic skeleton [21]. Therefore, as our fourth hypothesis, we expect that:

4. Arrow worms should remain small (compared, e.g., with other zooplanktivorous WBE, such as anchovies) and exhibit growth performances (requiring a high $\mathrm{O}_{2}$ supply) that are very low (again compared to fishes).

Finally, with regards to reproduction and given the GOLT, we suggest that:

5. In a given population, chaetognaths reach maturity at a fraction of their maximum length that is similar to the fraction that would occur in fish of the same size.

\section{Materials and Methods}

\subsection{Taxonomy and Compilation of Chaetognath Life Traits}

Five main databases were primarily consulted for gathering data. WoRMS was used to provide the current chaetognath taxonomy [1], and distributions that included point data came from OBIS [22]. The Biodiversity Heritage Library [23] was used to consult the early taxonomic works. Additional taxonomic data were also extracted from information compiled in the framework of LifeWatch Greece [24]. SeaLifeBase [2] was used to obtain maximal lengths and benthic/benthopelagic/pelagic assignments, adapted mainly from the "Chaetognatha of the World" website [25]. Species authorities are given in Supplementary Materials S1.

When the required data were missing in these databases, they were mainly extracted from the original descriptions, following a search for other taxonomic and systematic literature. This was the case for species described since the mid-1980s, and for the minute species in the family Spadellidae, which generally have a restricted distribution area, both of which include many species known only from their original descriptions. 
Latitudinal ranges were estimated visually from maps based on OBIS occurrence records, from the geographic coordinates of the type localities, or from the literature.

The mean latitude (LAT) was computed from the latitudinal range as the mean of the averages in two hemispheres, and rounded to the closest $\frac{1}{4}$ of a degree, as follows:

$$
\begin{gathered}
\text { LatNRM = northernmost latitude, LatSRM }=\text { southernmost latitude } \\
\text { LAT }=(\mid \text { LatNRM }-0|/ 2+| 0-\text { LatSRM } \mid / 2)) / 2=(\mid \text { LatNRM }|+| \text { LatSRM } \mid) / 4
\end{gathered}
$$

The list of the 132 currently valid species of chaetognath, their mean latitude of occurrence, occurrence along China's coast $(\mathrm{Y} / \mathrm{N})$, habitat assignments (pelagic, benthopelagic, and benthic), and maximum body lengths $(\mathrm{mm})$ are documented in Supplementary Materials (Table S1).

\subsection{Morphometrics}

To enable us to estimate the volume (and hence the weight) of individual arrow worms from their lengths, we assumed that their body is composed of successive cylinders, each with a different circumference, as estimated from successive width of the drawings representing them. For each cylinder, the maximum rectangular area $(S)$, as well as the length of the rectangle, i.e., the height of the cylinder $(h)$, was obtained by using the ImageJ software. Then, the width of the rectangle, i.e., the diameter of the cylinder $(R)$, can also be calculated according to $R=S / h$, while the volume can be computed from $V=\pi r^{2} h$, where $r=R / 2$. The head of an arrow worm can be taken as a half-sphere. The volume of a sphere is $(4 / 3) \pi r^{3}$, and half of that is $V=(2 / 3) \pi r^{3}$. Thus, we obtained the volume of an arrow worm by adding successive cylinders to a half sphere.

\subsection{Growth, Growth Comparisons, and Longevity}

The concepts to be presented below apply to animals that breathe in water (i.e., WBE), and thus can be applied to arrow worms. The growth of WBE can be represented by

$$
\mathrm{d} W / \mathrm{d} t=H W^{d}-k W
$$

where $\mathrm{d} W / \mathrm{d} t$ is the rate of growth in terms of weight-W (or more precisely mass), $d$ is a scaling factor $<1$, and $H$ and $k$ are coefficients expressing the synthesis of the body's proteins ("anabolism") and the denaturation of the same proteins ("catabolism"), respectively. As defined here (see Pauly $[15,16]$ for details), anabolism is proportional to the oxygen $\left(\mathrm{O}_{2}\right)$ supply to the body because $\mathrm{O}_{2}$ and, hence, ATP are required for synthesis. On the other hand, catabolism is weight-proportional because all protein molecules in the body, due to thermal noise, lose the quaternary structure required for their specific functions at rates that determine their half-lives [26-28].

If the scaling factor $d$ in Equation (3) is assumed to be equal to $2 / 3$, this equation can be integrated into a growth curve known as the von Bertalanffy growth function (VBGF), which has the following form:

$$
L_{t}=L_{\infty}\left(1-\mathrm{e}^{-K \cdot\left(t-t_{0}\right)}\right)
$$

where $L_{t}$ is the mean length at age t of the animals in question, $L_{\infty}$ their asymptotic size, i.e., the mean size attained after an infinitely long time, $K$ expresses how fast $L_{\infty}$ is approached (herein, year ${ }^{-1}$ ), with longevity $\approx 3 / K$, and $t_{o}$ is a parameter adjusting for the fact that the VBGF usually fails to describe the growth of the earliest (larval) stages of WBE. Thus, $t_{0}$, by representing the age WBE would have at a size of zero, if they had always grown in the manner predicted by the equation, allows the VBGF to correctly represent length-at-age in post-larval stages [19]. 
The VBGF for length growth can be straightforwardly transferred into an equation for growth in weight by combining a length-weight relationship (LWR) of the form: $W=a \cdot L^{b}$ with Equation (4). The VBGF for growth in weight is, thus,

$$
W_{t}=W_{\infty}\left(1-e^{-K \cdot\left(t-t_{0}\right)}\right)^{b}
$$

where $W_{\infty}$ is the weight corresponding to $L_{\infty}, b$ is the allometry coefficient, and all other parameters are defined as above.

The literature on the growth of chaetognaths includes many examples of growth curves whose author(s) presupposed slow growth. This has resulted in "cohorts" being subjectively created whose growth curves extended to well over a year, sometimes two [29,30], and including long periods of near-zero growth at minuscule sizes (see, e.g., Zo [31]).

Here, rather than tracing our own growth curves and adding to the confusion, we analyzed a set of previously published "mass-at-age" data generated by Hirst and Foster [32] based on aquarium experiments (see Supplementary Materials, Table S2). We fitted Equation (5) with $b=3$, using Microsoft Excel's Solver routine after removing the data point representing larval growth (the deleted data points are documented in Table S2).

For comparisons of growth performance within and between different chaetognaths species, and between chaetognaths and other WBE, one can use the index

$$
\varnothing_{\prime}=\log (K)+2 \cdot \log (L)
$$

which is relatively constant within species (and higher taxa with similar shapes), as assessed by studying and relating hundreds of $L_{\infty}-K$ data pairs (see Pauly $[15,19]$, Binohlan and Pauly [33]; see also "Life history" in FishBase [13]). However, to allow for comparisons that take into account the different shapes that different clades of WBE can have, we use the index

$$
\varnothing_{\prime}=\log (K)+2 / 3 \cdot \log (W)
$$

which assumes LWRs with slopes $b=3$, as commonly occurs in WBE.

\subsection{Oxygen, Temperature, and Arrow Worms}

The total amount of $\mathrm{O}_{2}$ which can diffuse into the body of a WBE per unit time follows Fick's law of diffusion:

$$
Q^{\prime}=\mathrm{d} P \cdot U \cdot G / W B D^{-1}
$$

where $Q^{\prime}$ is the oxygen uptake $\left(\mathrm{mL} \cdot \mathrm{h}^{-1}\right)$; $\mathrm{d} P$ is the difference between the oxygen partial pressure on either side of the respiratory membrane (in atm); $U$ is Krogh's diffusion constant, that is, the amount of oxygen (in $\mathrm{mL}$ ) which diffuses through an area of $1 \mathrm{~mm}^{2}$ in one minute for a given type of tissue (or material) when the pressure gradient is one atmosphere (1013.25 $\mathrm{hPa}$ ) of oxygen per $\mu$ (micron); $G^{\prime}$ is the total respiratory surface, and $W B D$ is the water-blood distance, that is, the thickness of the tissue between the surrounding water and the interior of the body in $\mu$ [34].

Of the four parameters of Equation (8), which determine the value of $Q^{\prime}$, only $G^{\prime}$ may be assumed to vary greatly as body size increases, thus making the respiratory surface area the key factor limiting oxygen uptake in WBE. The GOLT is structured around the fact that gills, because they have to function as a $2 \mathrm{D}$ surface in contact with the water that delivers oxygen, cannot keep up with the growing 3D bodies they have to supply with oxygen.

\subsection{Reproduction}

In fishes, mean length at first maturity $\left(L_{m}\right.$, i.e., the length at which $50 \%$ of the individuals are mature) occurs at $L_{\max }{ }^{D} / L_{m}{ }^{D} \approx 1.35$, with $D=3(1-d)[16,35,36]$.

Here, we also tested whether chaetognaths reach maturity and spawn at a fraction of their maximum length $\left(L_{\max }\right)$ that is similar to that of fishes. Note that since postlarval chaetognaths maintain their basic shape as they grow, their integument (i.e., their 
respiratory surface) should grow in proportion to $2 / 3$ of their weight, i.e., $d \sim 0.67$. Given its definition, this means that, for chaetognaths, $D=1$, and, hence, $L_{\max }{ }^{D} / L_{m}{ }^{D}=L_{\max } / L_{m}$.

\section{Results}

\subsection{Early Illustrative and Taxonomic Work on the Chaetognatha, or Arrow Worms}

The first published record and drawing of an arrow worm, from the North Sea, are in Slabber [37] (46-48; Pl. 6, S4), where it was described as a "sea-worm". Slabber coined the Latin name Sagitta (arrow) and the Dutch name "pyl" ("pijl" = arrow) for his sea-worm. For the precise dates of Slabber's publication, see Hoeven [38], Benthem Jutting [39], and WelterSchultes [40]. Sagitta Slabber, 1771 is not "available" as a generic name in nomenclatural terms because he did not describe a species or refer to an existing one. The drawing was later identified as Parasagitta setosa (J. Müller, 1847) [41].

In 1825, Blainville mentions a genus within a family of pelagic mollusks as "G. Sagitelle Lesueur" [42] (T1:492), noticing that Lesueur described that genus and one species from "warm seas", but that it may represent several species. In a complementary note dated from 1827 [42] (T2:656), he explained that Lesueur had described Sagitella aequipinnis and two other species (whose names were not cited) from the Caribbean Sea, in a manuscript, "Monog. des Ptérop. Pl. 11, Figures 1-3", that was apparently never published ([43], p. 645). In another publication dated from the same year, Blainville [44], who obviously had access to that manuscript, detailed the description of the three species under the French common and Latin scientific names coined by Lesueur: Sagitella aequipinnis, Sagitella tuberculata, and Sagitella inaequipinnis.

Blainville also listed Sagitta (with the species name Sagitta bipunctata Quoy \& Gaimard [45]) with this comment: "MM. Quoy et Gaimard viennent d'établir sous cette dénomination un petit genre de malacozoaires, qui semble être extrêmement rapprochés des sagittelles de M. Lesueur." (MM. Quoy and Gaimard just established under that name a small genus of malacozoa, which seems very close to the sagitelles of M. Lesueur). This has been overlooked by most of the subsequent authors, except Eydoux and Souleyet [43]. The possible nomenclatural anteriority within the year 1827 remains to be investigated since only a French vernacular generic name was mentioned without a species in 1825, along with the homonymies of the genus.

The first valid description of a chaetognath species currently recognized is from 1827, and pertains to Sagitta bipunctata from Gibraltar (Quoy and Gaimard [45] (232, Pl. 8C, S4). Shortly thereafter, Charles Darwin sketched an arrow worm in his "H.M.S. Beagle" field notes [46] and later wrote about their abundance and biology [17], citing d'Orbigny [47] and Forbes [48] who had meanwhile described three and two new species, respectively (see also Barrett et al. [49], p. 78 and 479).

The name Chaetognathi ("bristle jaws"), was coined by Leuckart when he proposed that the genus Sagitta should be separated from the other groups of "Vermes": "At the moment, it seems most natural to regard the Sagittas as representatives of a small group of their own that makes the transition from the real annelids (first of all the lumbricines) to the nematodes, and may not be unsuitably named [Chaetognathi]." ([50], p. 335; translated from German).

This settled the issue of the identity of chaetognaths, which until then had been viewed as mollusks, annelids (oligochaetes), nematodes, gordians, gephyreans, and tardigrades. Eventually, Leuckart ([51], p. 117) emended Chaetognathi to Chaetognatha in a short note reiterating his conclusions. Hertwig [52] endorsed that name: "Gegenbaur ([53], p. 138) called the newly created division the Oesthelminthes, Harting ([54], p. 617) the Pterhelminthes and Leuckart ([50], p. 335) the Chaetognaths [Chaetognathen]. I keep this latter name for the description of the order, since it has priority and it has become common in literature." ([52], p. 8; translated from German).

After Leuckart [50], and before "phylum" was commonly used as a taxonomic rank, the chaetognaths were variously listed as an order or a class in Vermes. This ended when Grassi ([55], p. 5) separated them as a group with unknown affinities. Today, molecular studies have clearly demonstrated that they have protostomian rather than 
deuterostomian affinities (e.g., [56,57]) as was long thought because of their peculiar ontology. However, these studies have failed so far to firmly establish their sistership in that lineage. Several hypotheses were tested for the past 25 years without a clear consensus, although the latest analyses related them to the Gnathifera (e.g., [58]). Barthélémy and Casanova [59] even provided a reappraisal of the molluscan sistership hypothesis, ironically their first placement by Blainville ex Lesueur [42,44] and Quoy et Gaimard [45], based on morphoanatomical and other zoological methods. Under both hypotheses, however, the chaetognaths would remain within the Spiralia clade.

After 1844 and until 1910, 66 species and five genera were described. Ritter-Záhony [60] published the first and only exhaustive revision of the group together with two new species, but reduced the number of valid species to 27 in six genera, and 16 incertae sedis species. No family was defined.

After 1911 and until 1965, 52 species and six genera were described. Tokioka [61] reviewed the classification by establishing two classes, two orders (and two suborders), four families, and six genera, validating 58 species (and seven infraspecific taxa) in 15 genera and five families (of which four were new ones), and 11 incertae sedis species. The class Archisagittoidea contained the fossil Amiskwia sagittiformis Walcott, 1911 (now seen as a stem group of Chaetognatha but a crown group of Gnathifera [62], or a stem group of the Gnathostomulida or the Gnathifera [63], both hypotheses remain in the Gnathifera clade). He divided the class Sagittoidea established for the extant species into two orders, Aphragmophora and Phragmophora. Several further attempts to establish new subclasses, orders, or suborders (including those of Tokioka) failed to survive subsequent morphoanatomical and molecular analyses.

Tokioka's general classification (with adaptations by Bieri $[64,65]$ ) is still in use with the additional taxa described since, and today contains 132 valid species in 26 genera, nine families, and two orders [1] (Table S1). Several unequivocal fossil chaetognaths have been described (e.g., $[66,67])$, but placed each in their own family without ordinal classification. Gasmi et al. [68] proposed some adjustments based on their most comprehensive molecular phylogeny so far, but their suggestions have not yet been integrated in a proper taxonomic framework.

\subsection{Chinese Studies on Arrow Worms}

A total of 37 chaetognath species are reported from China's waters [69] (see also Table S1), where they are distributed over a wide range of depths.

Research on the chaetognaths of China began in 1919 with the investigation of the "Albatross" [70]. However, with the exception of Hsü [71] reporting chaetognaths from China's coastal areas, and Sproston [72] from the waters of the Zhoushan Archipelago, there was no follow-up until the late 1950s, when China launched successive surveys of marine systems and fishery resources. These surveys included zooplankton studies, especially the national comprehensive marine survey from 1958 to 1960, which laid the foundation for China's research on chaetognaths.

The initial research on chaetognaths in Chinese coastal areas mainly focused on their taxonomy and occurrence. In the 1980s, the research interest began to shift to chaetognath ecology, such as species composition [73,74], species diversity [75], quantitative distribution $[76,77]$, vertical movement [78], ecology, including the relationship with oceanographic features [79-82], and feeding ecology [83].

However, most of these studies were based on survey data, and experimental research on the ecology of chaetognath is still rare. Liu et al. [84] conducted preliminary studies on the tolerance to temperature and salinity in Aidanosagitta crassa, which established that their survival rates were higher at lower temperatures. Liu et al. [85] also studied the effects of different temperature and salinity on the oxygen consumption rate of $A$. crassa. Based on monthly sampling data at a station in Jiaozhou Bay in the Yellow Sea in 2006, Huo et al. [86] demonstrated a negative relationship between body length and average water temperature in A. crassa (see below). 


\subsection{Body Length in 132 Species: Relation to Temperature and Habitat}

The maximum recorded body lengths ( $B L$, in $\mathrm{mm}$ ) for the 132 species of chaetognaths currently recognized were related to the mean latitude of their distribution range (LAT, in degrees north or south; a proxy for temperature $[87,88])$ and their habitat through the multiple regression

$$
\log (B L)=0.616+0.445 \cdot \log (L A T)-0.580 \cdot B-0.354 \cdot B P
$$

where $B$ is a dummy variable ( $B=1$ for benthic and 0 for pelagic and benthopelagic species), and $B P$ is another dummy variable ( $B P=1$ for benthopelagic and 0 for pelagic and benthic species).

The multiple correlation coefficient $\mathrm{R}=0.573$, which implies that this model, with $\mathrm{R}^{2}=0.329$, explains more than $30 \%$ of the variance in the dataset in Supplementary Table S1. In addition, its partial slopes have the expected signs and are significantly $\neq 0(p<0.001$; see Table 1). Equation (9) implies that chaetognath species tend to be smaller the closer they are to the equator, but also that the 14 benthic speces are, on average, 3.8 times smaller than the 77 pelagic species, while the 41 benthopelagic species tend to be 2.3 times smaller than the pelagic species, i.e., intermediate, as may be expected (Figure 2). Figure 2 also suggests that some species are misclassified, e.g., benthopelagic species labelled as pelagic or benthic species.

Table 1. Estimated coefficients of a multiple regression of $\log$ (body length) against log(latitude) and two dummy variables defining the habitat of three groups of chaetognath species ${ }^{\text {a }}$.

\begin{tabular}{ccccccc}
\hline Parameter & Coeff. & SE & t-stat. & $p$-Value & Lower 95\% & Upper 95\% \\
\hline Intercept & 0.632 & 0.153 & 4.124 & 0.000066 & 0.329 & 0.936 \\
\hline $\log ($ LAT) & 0.445 & 0.114 & 3.880 & 0.000166 & 0.218 & 0.672 \\
\hline B (benthic) & -0.580 & 0.086 & -6.711 & $<0.00001$ & -0.752 & -0.408 \\
\hline BP (benthopelagic) & -0.354 & 0.062 & -5.726 & $<0.00001$ & -0.477 & -0.232 \\
\hline
\end{tabular}

a There are 77 pelagic species (with $\mathrm{B}$ and $\mathrm{BP}=0$ ), 14 benthic, and 41 benthopelagic species.

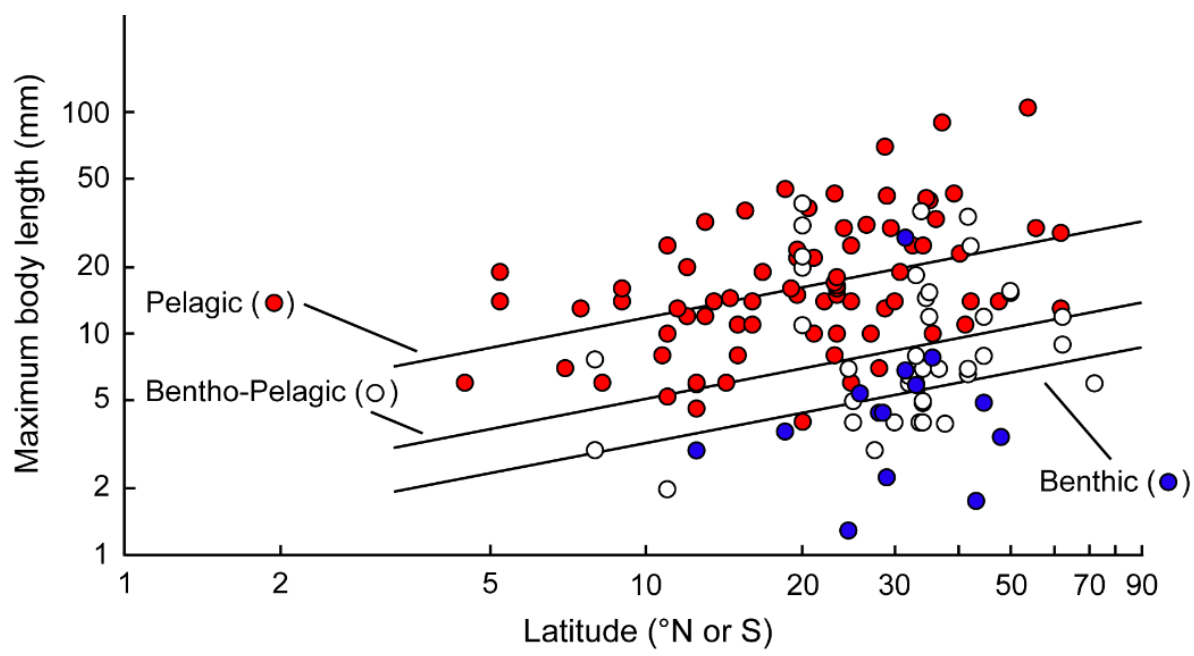

Figure 2. Relationship between the maximum body length of the 132 species of extant chaetognaths and the mean latitudes of their distribution ranges (as proxy for sea surface temperature); see also Equation 9 and Table S1. On average, pelagic species $(n=77)$ are 2.3 times longer than benthopelagic species $(n=41)$ and 3.8 times longer that benthic species $(n=14)$. This figure also suggests that the habitat of some of the species in Table S1 may have been wrongly assigned. 


\subsection{Body Lengths in Three Chaetognath Species Experiencing Different Water Temperatures}

Figure 3 presents size-temperature relationships in three chaetognath species, Parasagitta elegans, Aidanosagitta crassa, and Ferosagitta hispida, based on data published by McLaren [89], Zo [31], Huo et al. [86], Reeve [3], Reeve and Walter [90], and Reeve and Baker [91].

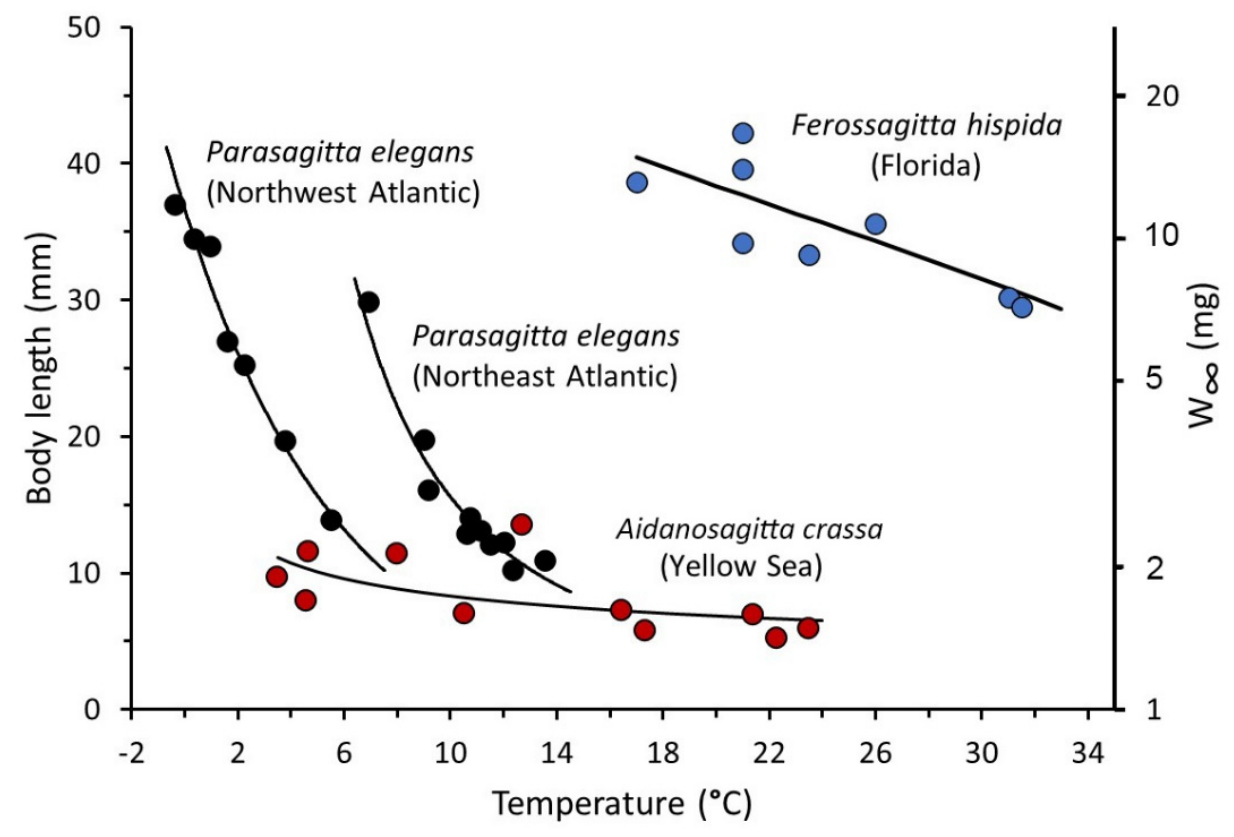

Figure 3. Relationship between the size (body length or $\mathrm{W}_{\infty}$, i.e., asymptotic weight) of 3 species of chaetognaths and the mean temperature of the water in which they live or were raised. The body lengths and the curves for Parasagitta elegans (black dots) in the North Atlantic were redrawn from Figure 1 in McLaren [89], and the (red dots) points for Aidanosagitta crassa in the Yellow Sea are from Huo et al. [86], with a curve replacing their straight line. The blue dots refer to Ferosagitta hispida from coastal waters in Florida (based on data from Reeve [3], Reeve and Baker [91], and Reeve and Walter [90]), see text.

As might be seen, body size in these three species and, by extension, in other chaetognaths as well, decreases with temperature, as predicted by the GOLT.

\subsection{Morphometrics and Growth of Chaetognaths}

Table S3 presents estimates of the surface area of the body of six species of chaetognaths (excluding fins), and the corresponding volume of their bodies, based on published drawings of adult specimens. These data allowed two general patterns to be established (Figure 4). One is that the surface area of the body of chaetognaths $(S)$ can be predicted from their body length $(L)$, using $S=0.232 \cdot L^{1.92}$ when the surface is in $\mathrm{mm}^{2}$ and the length in $\mathrm{mm}$ (Figure $4 \mathrm{~A}$ ). The other is that the relative surface of the body (i.e., the respiratory surface per unit volume) declines with volume $(S / V$; Figure $4 \mathrm{~B})$ according to $S / V=511 \cdot \mathrm{L}^{-0.90}$ when $S / V$ is expressed in $\mathrm{cm}^{2} \cdot \mathrm{g}^{-1}$ and length in $\mathrm{mm}$. In both cases, the relationships are near isometric, with the former relationship not significantly lower than 2 , and the latter not significantly higher than -1 . 


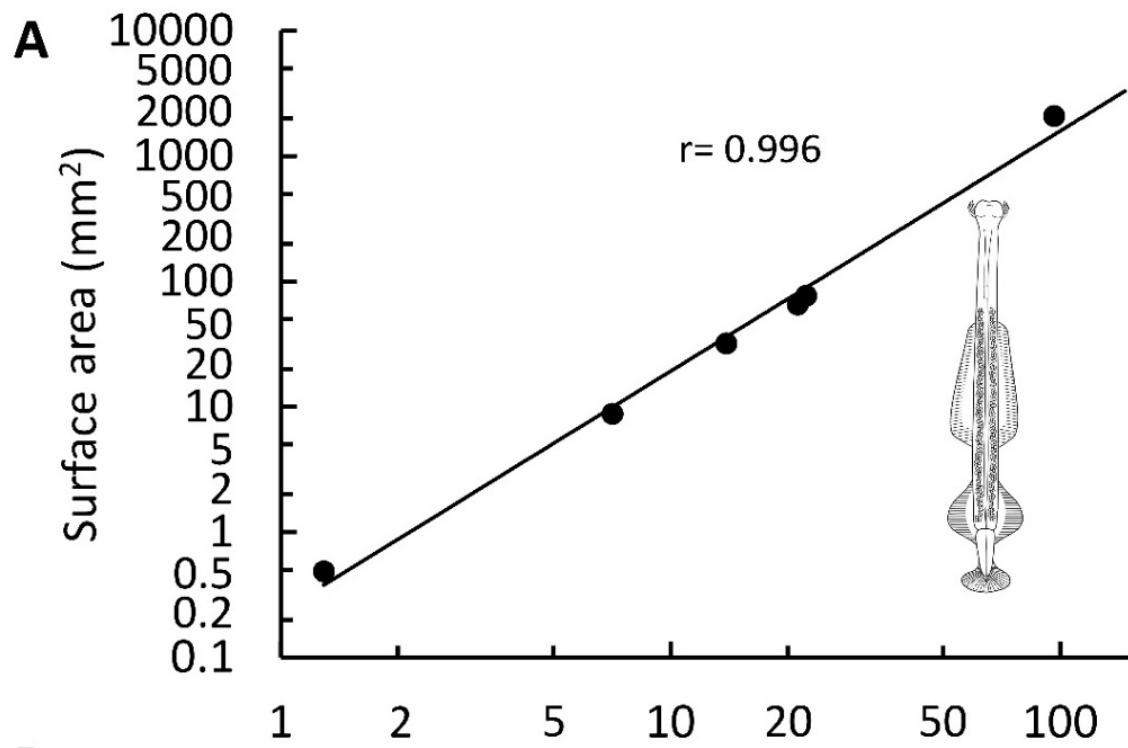

B

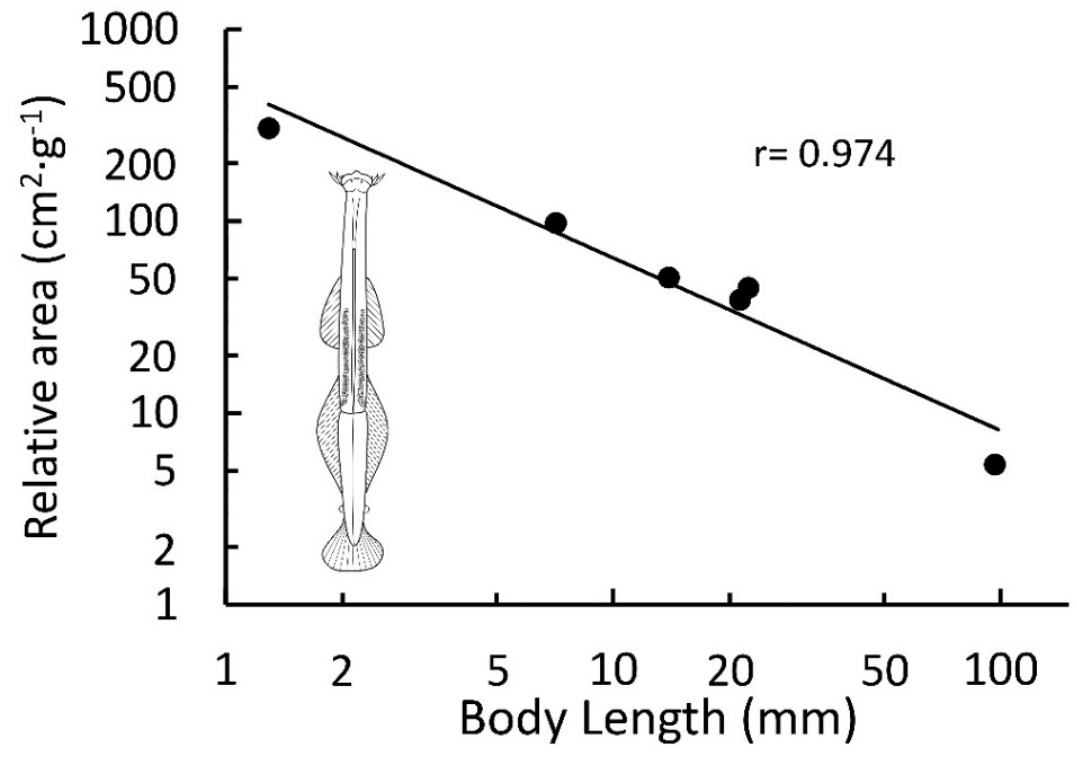

Figure 4. Demonstrating the relationships between the body length of 6 individual chaetognaths representing 6 species, (A) the surface area of their bodies (fins excluded), and (B) their surface area/volume (based on the measurements in Table S3).

The latter trend establishes that large chaetognaths will be challenged in acquiring, by diffusion through their integument, the oxygen they need to sustain their activity and growth. This is the reason why the largest chaetognath, Pseudosagitta gazellae, reaching $10.5 \mathrm{~cm}$, occurs only in Antarctic water, where the low temperature keeps its oxygen requirement low, and perhaps also why the water content of chaetognaths appears to increase with their size (Table 2). 
Table 2. Dry weight of chaetognaths in \% of their wet weight.

\begin{tabular}{ccccc}
\hline Species & BL $^{\text {a }}$ & Location & \% Dry Weight & Source \\
\hline P. gazellae & 105 & Antarctica & 5.3 & Ikeda and Kirkwood [6] (Table 2) \\
\hline P. elegans & 30 & NS, Canada & $9.0-10.9$ & Pearre [92] (Table 4); Harrison [93] \\
\hline Z. nagae & 25 & East China Sea & 7.7 & Feng [94], p. 56 \\
\hline P. setosa & 14 & Off Plymouth & 9.3 & Harrison [93] (Table I) \\
\hline F. hispida & 11 & Near Miami & 15.2 & Reeve et al. [95] (Table 1) \\
\hline A. crassa & 10 & Yellow Sea & 14.4 & Feng [94], p. 51 \\
\hline 12 species & - & Various & 9.3 & Thuesen and Childress [97] (Table 1) \\
\hline Several spp. & - & Various & 10.0 & Table 1)
\end{tabular}

Sameoto [98], working with Pseudosagitta elegans, obtained a mean slope of 0.69 for the relation between the logarithm of their metabolic rate and their (dry) weight (see Ikeda and Kirkwood [6]); similarly, Kruse [99] (p. 119/120) obtained a mean slope of 0.664. This justifies the use of the VBGF not only to describe empirically the growth of arrow worms, but also as a "physiologically correct" model of their growth, because the parameter $d$ in Equation (3), which is assumed to be $2 / 3$ in the VBGF, actually took values near 0.667 in chaetognath respiration studies.

On the other hand, the data in Table 2 show that the chaetognaths with dry weights that are about $10 \%$ of their wet weights are intermediate between the jellyfish, with 5 to $2 \%$ [100] and other WBE with 20-30\% [101,102]. Note the tendency for large species to have a higher water content, confirming Kiørboe [96].

Fitting the "mass-at-age" data for Sagitta hispida in Table S2 and the observed size-atage data of Reeve [3] with Equation (5) yielded the growth parameters in Table 3 and the growth curves in Figure 5.

Table 3. Growth parameters of Ferosagitta hispida raised in aquaria and estimated from "mass-at age" data of Hirst and Foster [32], as documented in Tables S2A and S2B (panels A-G in Figure 5) and size-at-age data in Figure 2 of Reeve [3], as documented in Table S2B (panel H in Figure 5). All samples originated from coastal water in Florida, USA.

\begin{tabular}{|c|c|c|c|c|c|c|}
\hline Case & $\operatorname{Temp}\left({ }^{\circ} \mathrm{C}\right)$ & $W_{\infty}(\mathrm{mg})^{a}$ & K (year $\left.{ }^{-1}\right)$ & $t_{0}($ year $)$ & $\varnothing^{b}$ & Data Sources \\
\hline $\mathrm{A}$ & 21 & 16.7 & 31.09 & 0.0045 & 0.308 & $\begin{array}{c}\text { Reeve and Baker [91] } \\
\text { (Figure 1) }\end{array}$ \\
\hline B & 31 & 7.5 & 88.07 & 0.0024 & 0.528 & $\begin{array}{c}\text { Reeve and Baker [91] } \\
\text { (Figure 1) }\end{array}$ \\
\hline $\mathrm{C}$ & 17 & 13.1 & 41.75 & 0.0072 & 0.367 & $\begin{array}{c}\text { Reeve and Walter [90] } \\
\text { (Figure 3) }\end{array}$ \\
\hline $\mathrm{D}$ & 21 & 14 & 43.79 & 0.0077 & 0.406 & $\begin{array}{c}\text { Reeve and Walter [90] } \\
\text { (Figure 3) }\end{array}$ \\
\hline $\mathrm{E}$ & 23.5 & 9.2 & 72.51 & 0.0037 & 0.504 & $\begin{array}{c}\text { Reeve and Walter [90] } \\
\text { (Figure 3) }\end{array}$ \\
\hline $\mathrm{F}$ & 26 & 10.7 & 83.67 & 0.0035 & 0.609 & $\begin{array}{l}\text { Reeve and Walter [90] } \\
\text { (Figure 3) }\end{array}$ \\
\hline G & 31.5 & 7.1 & 97.00 & 0.0027 & 0.556 & $\begin{array}{l}\text { Reeve and Walter [90] } \\
\text { (Figure 3) }\end{array}$ \\
\hline $\mathrm{H}$ & 21 & 9.8 & 53.37 & 0.0033 & 0.387 & Reeve [3] (Figure 2) \\
\hline
\end{tabular}

${ }^{\text {a }}$ Converted to wet weight by multiplying by 10 (see Table 2) the values in Table S2, and computed from lengths via $W=0.001 \cdot L^{3}$ (see text).

${ }^{\mathrm{b}}$ Computed with $W_{\infty}$ in $\mathrm{g}$, facilitate comparison with fishes; mean $\varnothing=0.458$. 
A)

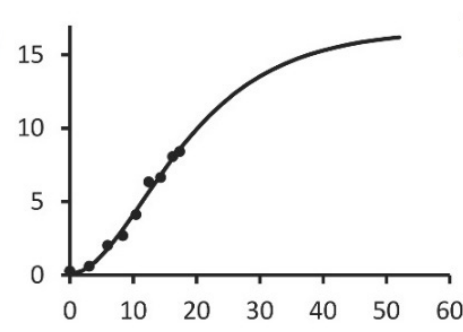

C)

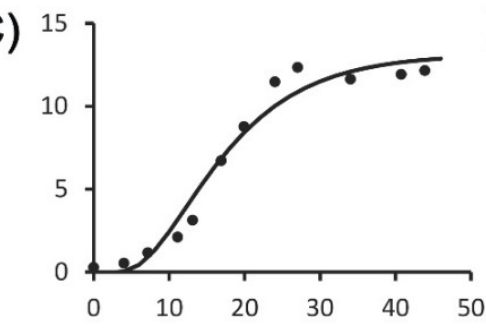

D) 15

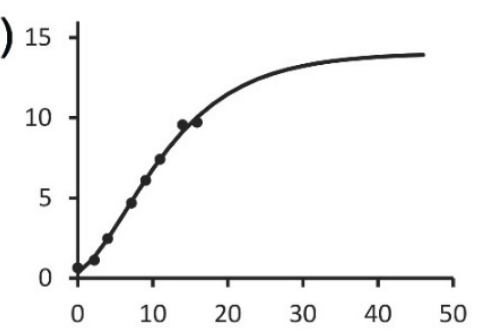

E)

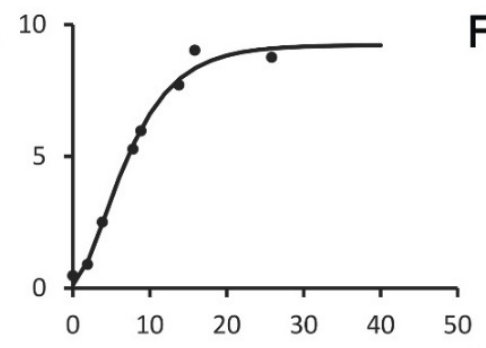

G)
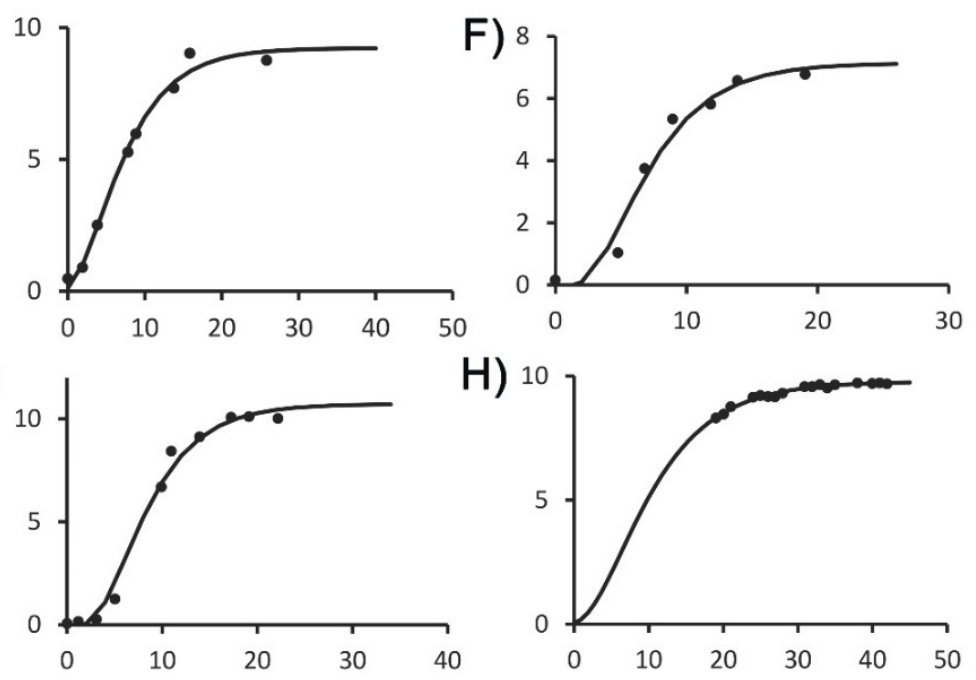

H)

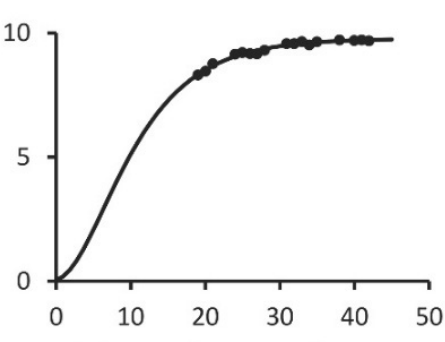

\section{Days after onset of post-larval growth}

Figure 5. Weight growth curves of Ferosagitta hispida based on the "mass-at-age" or length-at-age data converted to wet weight by multiplying by 10 the values in dry weight documented in Table S2. Case (A-H) (see also Table 3).

Table 4 compares the growth of Ferosagitta hispida (and the inferred growth of Pseudosagitta gazellae) to that of a few fish species, illustrating how limited the growth performance of chaetognaths is, compared to even slow-growing fishes.

Table 4. Comparison between the growth performance of 6 species of fish and 2 species of chaetognaths.

\begin{tabular}{|c|c|c|c|}
\hline Species $^{a}$ & $W_{\infty}(g)$ & $K\left(\right.$ year $\left.^{-1}\right)$ & $\varnothing\left(\log K+2 / 3 \log W_{\infty}\right)$ \\
\hline Thunnus albacares & 198,940 & 0.250 & 2.93 \\
\hline Morone saxatilis & 17,543 & 0.186 & 2.10 \\
\hline Mugil cephalus & 13,890 & 0.110 & 1.80 \\
\hline Trigla gurnardus & 534 & 0.312 & 1.31 \\
\hline Callionymus lyra & 53 & 0.490 & 0.84 \\
\hline Cottus bubalis & 102 & 0.230 & 0.70 \\
\hline Pseudosagitta gazellae $\mathrm{b}$ & $\approx 1$ & $(4.86)$ & $(0.458)$ \\
\hline Ferrosagitta hispida ${ }^{\mathrm{c}}$ & $\approx 0.01$ & 55 & 0.458 \\
\hline
\end{tabular}

${ }^{a}$ The 6 species of fish are documented in Pauly (1981). ${ }^{b}$ Assuming that the mean $\varnothing$ estimates from Table 3 also applies to $P$. gazellae. ${ }^{\text {c See Table } 3 .}$ 


\subsection{Reproduction in Chaetognaths}

Figure 6, based on Table 5, shows that in chaetognaths, $L_{\max }$, when plotted vs. $L_{m}$ in a regression with zero intercept, leads to a slope of 1.30, which is close to the estimate of 1.35 for teleosts [35,36], and well within its 95\% confidence interval of 1.22-1.53 (see Pauly [16]). This suggests that maturity, in chaetognaths, is triggered by the oxygen supply to their tissues dropping, as they grow and their surface area/volume ratio declines, to a level near 1.3 times their maintenance metabolism, as also occurs in fish [16,35].

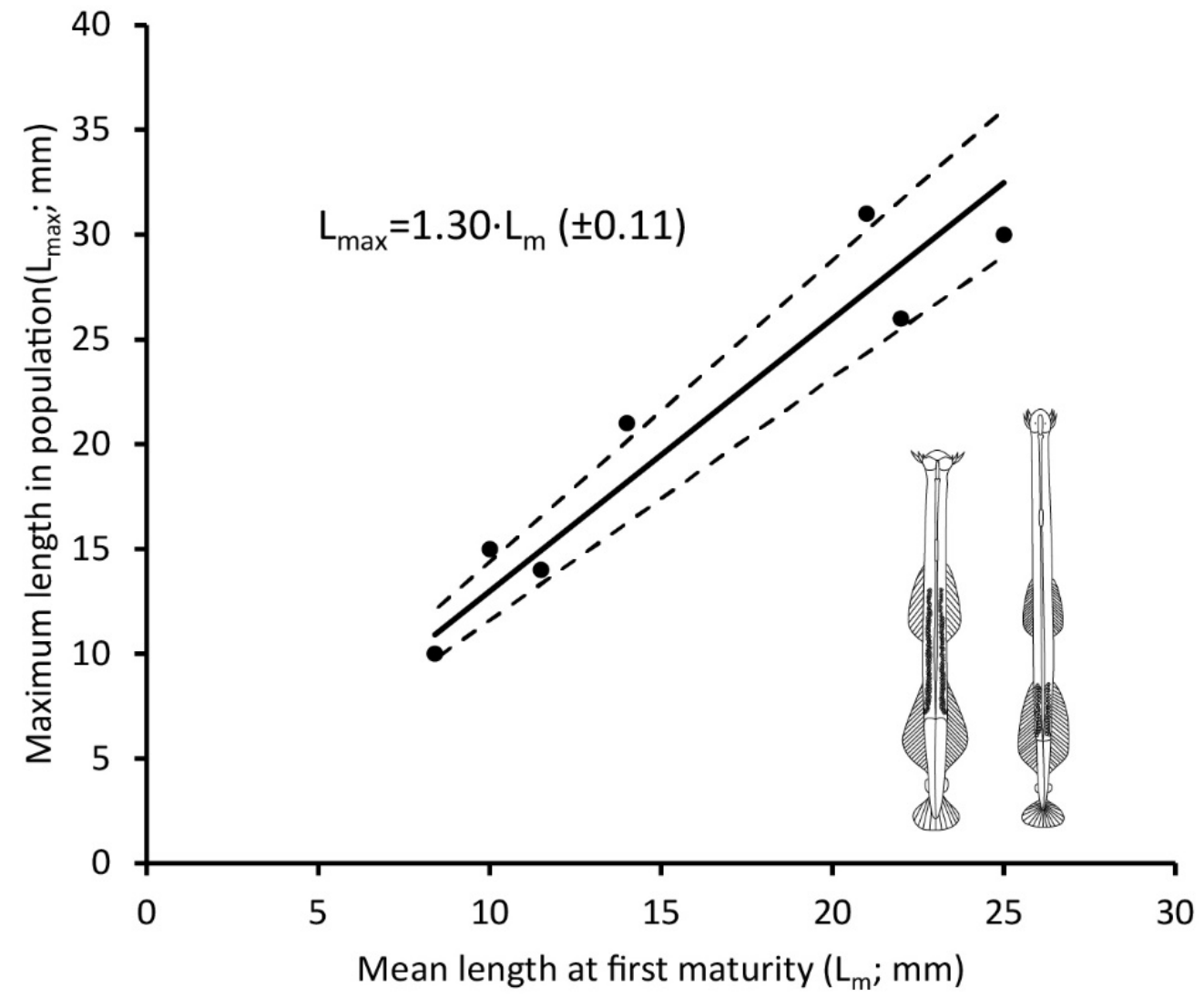

Figure 6. Maximum lengths $\left(L_{\max }\right)$ vs. lengths at maturity $\left(L_{m}\right)$ of 4 species chaetognaths ( $n=7$; from Table 5), fitted with a linear regression with a zero intercept. The estimated slope is 1.30 , with a $95 \%$ confidence interval (C.I.) of 1.19-1.41, which overlaps with the slope of $L_{\max }{ }^{D}$ vs. $L_{m}{ }^{D}$ in fishes (1.35; C.I. $=1.22-1.53)$; see text.

Table 5. Approximate length at maturity $\left(\mathrm{L}_{\mathrm{m}}\right)$ and maximum length ( $\left.\mathrm{L}_{\max }\right)$ of chaetognaths (in $\left.\mathrm{mm}\right)$.

\begin{tabular}{|c|c|c|c|c|}
\hline Species & Place/Time & $\mathbf{L}_{\mathrm{m}}$ & $\mathbf{L}_{\max }$ & Source \\
\hline P. elegans & $\begin{array}{l}\text { Bedford Basin, May-June } \\
1968\end{array}$ & 21 & 31 & Zo [31] (Figure 2) \\
\hline P. elegans & Plymouth, September 1930 & 10 & 15 & Russell [103] (Plate I) \\
\hline P. elegans & $\begin{array}{l}\text { Plymouth, May } 1930 \text { \& } \\
1931\end{array}$ & 14 & 21 & Russell [103] (Plate I) \\
\hline F. hispida & Laboratory, at $\sim 30^{\circ} \mathrm{C}$, & 8.4 & 10 & \multirow{2}{*}{$\begin{array}{l}\text { Reeves and Walters [90] } \\
\quad \text { (Figures } 3 \text { and } 4 \mathrm{~A})\end{array}$} \\
\hline F. hispida & Laboratory, at $\sim 17^{\circ} \mathrm{C}$, & 11.5 & 14 & \\
\hline E. bathypelagica & Lazarev Sea, Antarctica & 22 & 26 & Kruse [99] (Figure 1, p. 68) \\
\hline E. bathyantarctica & Lazarev Sea, Antarctica & 25 & 30 & Kruse [99] (Figure 2, p. 69) \\
\hline
\end{tabular}




\section{Discussion}

The distribution of the chaetognaths of both orders, the Aphragmophora and Phragmophora, is different between the two hemispheres; the former has 58 species in the Northern vs. 36 in the Southern Hemisphere, while for the Phragmophora, the corresponding numbers are 56 species in the Northern vs. 15 in the Southern Hemisphere (see Table S1). However, we think that this imbalance is due to a sampling bias rather than a phylogeographic signal. The Aphragmophora are mainly planktonic, and thus have been easily sampled during oceanographic campaigns or surveys, while the Phragmophora are mainly benthopelagic (Heterokrohniidae), and benthic (Krohnitellidae, Spadellidae), i.e., require the targeted and dedicated samplings that have been historically more frequent in the Northern than the Southern Hemisphere.

This becomes more evident when the planktonic Eukrohniidae are added to the Aphragmophora, resulting in 68 species in the Northern and 41 species in the Southern Hemisphere, vs. 48 species in the Northern and 10 species in the Southern Hemisphere for the Phragmophora without the Eukrohniidae.

Benthic chaetognaths are largely understudied around the world. It is symptomatic that many of the minute spadellid species are known only from the type specimens, and that the most recent one (Spadella kappae) was described near the "Station Biologique de Roscoff" [104,105], a French marine station established in 1872 on the coast of the English Channel, i.e., in one of the most intensively studied parts of the world's oceans.

The sampling bias hypothesis could be tested by checking the type localities; however, the time since the Spadellidae diverged from more generalized chaetognaths would have to be known. The hypothesis would be rejected if the Spadellidae arose recently in the Northern Hemisphere, and thus did not have time to radiate into much of the Southern Hemisphere. Unfortunately, Gasmi et al. [68] did not provide a time resolution which can be used for such a test.

While all the partial slopes of Equation (9) are significant (Table 1), Figure 2 makes it evident that it is only the pelagic chaetognaths that show a clear tendency toward increased size with increased latitude and the correspondingly higher sea surface temperature. Indeed, for deep benthic species, we should not expect marked changes of size with latitude, because deep-sea temperatures do not change much with latitude, if at all [106]. The observed pattern of size decline with latitude reflects a temperature trend that is well documented in other WBE, including fishes $[15,87,88]$, and it is commonly attributed to the direct impact of temperature on fish metabolism [16]. While other mechanisms could be hypothesized (see, e.g., [107]), they would need to also correlate with temperature and thus would be inherently be less parsimonious than the GOLT, which states that increasing temperatures themselves are the causes for size reduction in WBE [16].

What Figure 2 also suggests is that the habitat assignment of some species may have been erroneous, due to the fuzzy limits between "benthic" and "benthopelagic" modalities, and to uncertainty about the distance from the bottom where the specimens were collected. Habitat assignments, especially for the deep-sea species, while derived by experts, still require confirmation.

It is likely that the temperature-size relationship among chaetognath species in Figure 2 has the same cause as the temperature-size relationship within the three species in Figure 3. However, this relationship works at evolutionary scale in Figure 2, and at ontogenetic scale in Figure 3. The respiratory surface of chaetognaths, which grows approximately with length squared (Figure 4) and limits their oxygen supply (Equation (8)), cannot keep up with their oxygen demand, which grows approximately with length cubed and, similar to in other WBE, must increase when temperatures are high.

In captivity, fish and other WBE usually grow rapidly toward a smaller size than they reach in nature, resulting in lower asymptotic size (length and weight) and higher values of the parameter K when von Bertalanffy growth curves are fitted to their size-at-age data. This may also be the case for the growth curves in Figure 5 and the parameters in Table 3. In any case, 
these growth curves provide a realistic alternative to many of the hand-traced growth curves found in the literature, some of which suggest longevities as high as 2-3 years.

Indeed, the growth curves in Figure 5 may be realistic despite an early phase of larval growth having been assumed, i.e., the first data points in Table S2 were not used. At least some of the omitted points may correspond to the period between hatching and first feeding that is characteristic of chaetognath larvae, and which can last up to 10 days [108].

Even if preceded by a larval period, the growth curves in Figure 5 suggest that, at least for Ferosagitta hispida, the emergence and disappearance of a cohort would occur in a matter of about 2 months, which is possible given the small body length they reach $(\approx 1 \mathrm{~cm})$ and the high temperatures to which they were exposed. Thus, our results are compatible with Russell [109] who suggested 5-6 generations per year near Plymouth, and with the four, and six or seven generations per year reported by Murakami [110] and Nagasawa and Marumo [111], respectively, i.e., from areas in the U.K. and Japan that are cooler than Florida.

The $\varnothing$-values in Table 3 have a mean of $\varnothing=0.458$. Thus, the largest extant chaetognath, P. gazellae, with an asymptotic weight of $\mathrm{W}_{\infty} \approx 1 \mathrm{~g}$, would have a value of $K$ of $4-5$ year ${ }^{-1}$ (see Table 4), which is compatible with having a single cohort per year, as reported by Pearre [108], based on David [112].

Chaetognaths have always posed problems as to their identity and biology, mainly because of their bizarre anatomy, which is unrelated to that of other invertebrate phyla. However, we hope to have shown that concerning some of their physiological traits, they behave similar to other, better-studied WBE. Thus, we could demonstrate that chaetognaths behave as hypothesized, i.e.,

1. Species occurring in colder waters are generally larger than those in warmer waters.

2. Individual chaetognaths reach larger sizes in colder than in warmer waters.

3. The growth of chaetognaths can be described by the VBGF.

4. Chaetognaths remain small and exhibit low growth performance.

5. Chaetognaths mature at a fraction of their maximum size that is similar to that of fish of the same size.

Therefore, we conclude that the chaetognaths conform to the Gill-Oxygen Limitations Theory (GOLT), even though they lack gills.

While there are numerous studies on metabolic rate (i.e., $\mathrm{O}_{2}$ consumption) of chaetognaths $[30,97,98,113,114]$, very little thought has been devoted to how they breathe, i.e., how they transfer oxygen dissolved in the water surrounding them into their bodies. For example, there is no mention of breathing, respiration, or oxygen in the otherwise wonderfully detailed 12 chapters in the book The Biology of Chaetognaths [115].

One author [116] wrote about the long, flagella-like cilia in the gut of chaetognaths that these cilia "maintain a current in the gut lumen. This may be concerned with respiration or with the removal of dissolved excretory matter liberated by the intestinal cells. Neither circulation of body fluids nor excretory organs have been described in Spadella so it may be concluded that the intake of oxygen and the excretion of katabolites takes place at the surface of the body. If these processes occur at the surface of the gut, then some mean would be necessary to renew the water in the lumen. The cilia would provide this means." However, this is not realistic because it would require either a rapid throughflow (through the vent?) of ingested water or nearly constant swallowing and regurgitation of oxygen-depleted water, none of which has ever been observed.

We think it is unavoidable to infer that the integument of chaetognaths serves as their respiratory organ. However, the integument may be thinner (and thus, given Equation (8), more efficient for respiratory purposes) near the "corona", a group of "cilia arranged around a depression on the dorsal side of the head and/or neck" [117] (citing Kapp [118]). The corona is where the cilia generate a flow which contributes " 2 to 3 times more to the oxygen transport than diffusion does" [117].

However, Bleich et al. [117] conclude, "While the corona ( . . ) may incidentally support respiration, especially for the oxygen supply of brain, eyes and head muscles, this is most probably not its main function." They also note that "the continuous activity of the cilia of the corona 
means a considerable energy investment [119]. It lets us conclude that the corona and the generated flow are important to chaetognaths."

We cannot imagine a function more important for a small organism (which must acquire all the oxygen it needs by diffusion from the boundary layer of water adjacent to its integument) than to induce a flow that would renew the water surrounding them. Indeed, this is necessary if a high $\mathrm{O}_{2}$ gradient is to be maintained between the surrounding water and its integument.

The GOLT is built around the assumption that animals that must extract the oxygen they require from the water surrounding them will have increasing difficulties breathing as their size increases because the volume of their bodies grows in three dimensions, i.e., faster than the surface area of the gills or other organ through which the required $\mathrm{O}_{2}$ enters the body.

This "dimensional tension" not only affects growth, but causes the maximum size of WBE to be strongly dependent on temperature, because it not only limits the $\mathrm{O}_{2}$ content of water, but also increases their $\mathrm{O}_{2}$ requirements [120].

Demonstrating the limiting effect of size on growth itself and that high temperatures are associated with lower maximum sizes in WBE are both tests of the GOLT's generality. If positive, these tests suggest that the GOLT applies to the WBE in question.

Moreover, if the GOLT applies to a clade of WBE, other inferences can be drawn that may explain some of their other traits. For example, given the estimation of likely von Bertalanffy growth parameters illustrated in Table 4, their food consumption and food conversion efficiency can be estimated [14], as can their productivity, or P/B ratios [121].

These various inferences should facilitate the inclusion of chaetognaths into trophic models of marine ecosystems [122] as an explicit group, rather than an undifferentiated component of "zooplankton" as is currently carried out in most cases; see repository of the nearly 500 such models described by Colléter et al. [123]. They would also allow chaetognaths, despite their taxonomic isolation, to be perceived as responding to the influence of physical constraints in a manner similar to other small marine metazoans.

Supplementary Materials: The following are available online at https://www.mdpi.com/article/10 .3390/jmse9121397/s1. Table S1A: List of the 66 currently valid extant species of chaetognath belonging to the order Aphragmophora. Table S1B: List of the 66 currently valid species of chaetognath belonging to the order Phragmophora. Table S2: Weight-at-age data derived by Hirst and Forster [32] from aquarium growth experiments with Ferosagitta hispida by Reeve and Walter [90] and Reeve and Baker [91]. Table S3: Surface area (excluding fins) and volume of the body estimated from drawings of adult specimens of 6 species of chaetognaths. The relative area is in $\mathrm{cm}^{2} \cdot \mathrm{g}^{-1}$ to enable comparisons with other groups. Supplementary Materials S4: Detailed citation for old references.

Author Contributions: Conceptualization and writing: D.P., C.L. and N.B.; methodology, D.P., C.L. and N.B.; software: C.L. and E.C.; formal analysis: D.P., C.L. and E.C.; writing-original draft preparation, D.P. and N.B.; writing-review and editing, D.P., C.L., W.X., E.C. and N.B.; visualization D.P., C.L. and E.C.; supervision: D.P. and W.X.; project administration, D.P. and W.X.; funding acquisition D.P. and W.X. All authors have read and agreed to the published version of the manuscript.

Funding: D.P., E.C. and N.B. are supported by the Sea Around Us, a research initiative funded by a number of philanthropic foundations. N.B. would also like to thank Erik V. Thuesen (The Evergreen State College, Olympia, WA, USA) for information on chaetognath taxonomy, and the LifeWatch Greece infrastructure (MIS 384676), funded by the Greek Government under the General Secretariat of Research and Technology (GSRT), ESFRI Projects, National Strategic Reference Framework (NSRF). C.L. and W.X. acknowledge support from the National Natural Science Foundation of China (No. 31872568) and NSFC Shandong Joint Fund for Marine Ecology and Environmental Sciences (U1606404).

Institutional Review Board Statement: Not applicable.

Informed Consent Statement: Not applicable. 
Data Availability Statement: All data used are presented in the text, figures, and tables, including table listed as Supplementary Materials.

Acknowledgments: Not applicable.

Conflicts of Interest: The authors declare no conflict of interest.

\section{References}

1. Thuesen, E.V. Phylum Chaetognatha. Available online: http://www.marinespecies.org /aphia.php? $p=$ taxdetails\&id=2081 (accessed on 10 October 2021).

2. Palomares, M.L.D.; Pauly, D. SeaLifeBase. Available online: www.sealifebase.org (accessed on 2 May 2021).

3. Reeve, M.R. The biology of Chaetognatha. I. Quantitative aspects of growth and egg production in Sagitta hispida. In Marine Food Chains; Steele, J.H., Ed.; University of California Press: Berkeley, CA, USA, 1970; pp. 168-189.

4. Casanova, J.-P.; Perez, Y. A Dwarf New Spadella (Chaetognatha) from Bora Bay (Miyako Island, Japan). Cah. Biol. Mar. 2000, 41, 137-141. [CrossRef]

5. Ritter-Záhony, R. Die Chaetognathen der Gazelle Expedition. Zool. Anz. 1909, 34, 787-793. (In German)

6. Ikeda, T.; Kirkwood, R. Metabolism and Elemental Composition of a Giant Chaetognath Sagitta gazellae from the Southern Ocean. Mar. Biol. 1989, 100, 261-267. [CrossRef]

7. Feigenbaum, D.L. Food and feeding behaviour. In The Biology of Chaetognaths; Bone, Q., Kapp, H., Pierrot-Bults, A.C., Eds.; Oxford University Press: Oxford, UK, 1991; pp. 45-54. ISBN 978-0-19-857715-7.

8. Feigenbaum, D.; Reeve, M.R. Prey Detection in the Chaetognatha: Response to a Vibrating Probe and Experimental Determination of Attack Distance in Large Aquaria. Limnol. Oceanogr. 1977, 22, 1052-1058. [CrossRef]

9. Kimmerer, W.J. Selective Predation and Its Impact on Prey of Sagitta enflata (Chaetognatha). Mar. Ecol. Prog. Ser. 1984, 15, 55-62. [CrossRef]

10. Casanova, J.-P. Quatre Nouveaux Chaetognathes Atlantiques Abyssaux (Genre Heterokrohnia): Description, Remarques Éthologiques et Biogéographiques. Oceanol. Acta 1986, 9, 469-477.

11. Casanova, J.-P.; Barthélémy, R.-M.; Duvert, M.; Faure, E. Chaetognaths Feed Primarily on Dissolved and Fine Particulate Organic Matter, Not on Prey: Implications for Marine Food Webs. Hypotheses Life Sci. 2012, 2, 20-29.

12. Grigor, J.J.; Schmid, M.S.; Caouette, M.; St.-Onge, V.; Brown, T.A.; Barthélémy, R.-M. Non-Carnivorous Feeding in Arctic Chaetognaths. Prog. Oceanogr. 2020, 186, 102388. [CrossRef]

13. Froese, R.; Pauly, D. (Eds.) FishBase. Available online: www.fishbase.org (accessed on 2 May 2021).

14. Pauly, D. A Précis of Gill-Oxygen Limitation Theory (GOLT), with Some Emphasis on the Eastern Mediterranean. Mediterr. Mar. Sci. 2019, 20, 660-668. [CrossRef]

15. Pauly, D. Gasping Fish and Panting Squids: Oxygen Temperature and the Growth of Water Breathing Animals, 2nd ed.; Excellence in Ecology Series; International Ecology Institute: Oldendorf/Luhe, Germany, 2019; ISBN 978-3-946729-22-8.

16. Pauly, D. The Gill-Oxygen Limitation Theory (GOLT) and Its Critics. Sci. Adv. 2021, 7, eabc6050. [CrossRef] [PubMed]

17. Darwin, C. Observations on the Structure and Propagation of the Genus Sagitta. Ann. Mag. Nat. Hist. 1844, 13, 1-6. [CrossRef]

18. Bullock, T.H. Chaetognatha, Pogonophora, Hemichordata, and Chordata Tunicata. In Structure and Function in the Nervous Systems of Invertebrates; Chapter 27; Bullock, T.H., Horridge, G.A., Eds.; W.H. Freeman: San Francisco, CA, USA, 1965; Volume II, pp. 1559-1592.

19. Pauly, D. Beyond Our Original Horizons: The Tropicalization of Beverton and Holt. Rev. Fish Biol. Fish. 1998, 8, 307-334. [CrossRef]

20. Shinn, F. Chaetognatha. In Microscopic Anatomy of Invertebrates, Volume 15: Hemichordata, Chaetognatha, and the Invertebrate Chordates; Harrison, F.W., Ruppert, E.E., Eds.; Wiley-Liss: New York, NY, USA, 1997; pp. 103-220.

21. Bone, Q.; Duvert, M. Locomotion and Buoyancy. In The Biology of Chaetognaths; Bone, Q., Kapp, H., Pierrot-Bults, A.C., Eds.; Oxford University Press: Oxford, UK, 1991; pp. 32-44. ISBN 978-0-19-857715-7.

22. OBIS Ocean Biodiversity Information System. Intergovernmental Oceanographic Commission of UNESCO. Available online: www.obis.org (accessed on 1 June 2020).

23. Kalfatovic, M.R.; Costantino, G.; Rinaldo, C.A. The Biodiversity Heritage Library: Unveiling a World of Knowledge About Life on Earth. In Proceedings of the Digital Libraries for Open Knowledge; Doucet, A., Isaac, A., Golub, K., Aalberg, T., Jatowt, A., Eds.; Springer International Publishing: Cham, Switzerland, 2019; pp. 352-355.

24. Bailly, N.; Gerovasileiou, V.; Arvanitidis, C.; Legakis, A. Introduction to the Greek Taxon Information System (GTIS) in LifeWatchGreece: The Construction of the Preliminary Checklists of Species of Greece. Biodivers. Data J. 2016, 4, e7959. [CrossRef] [PubMed]

25. Pierrot-Bults, A.C. Chaetognatha of the World. Zoological Museum, University of Amsterdam. Available online: http://www. species-identification.org/species.php?species_group=chaetognatha\&menuentry=index\&selected=wetenschappelijk (accessed on 10 October 2021).

26. Von Bertalanffy, L. Theoretische Biologie. Zweiter Band: Stoffwechsel, Wachstum; A. Francke Verlag: Bern, Germany, 1951. (In German)

27. Von Bertalanffy, L. Principles and theory of growth. In Fundamental Aspects of Normal and Malignant Growth; Nowinski, W.W., Ed.; Elsevier: Amsterdam, The Netherlands; New York, NY, USA, 1960; pp. 137-259. 
28. Cox, M.M.; Nelson, D.L. Lehninger Principles of Biochemistry, 5th ed.; W.H. Freeman and Company: New York, NY, USA, 2008; ISBN 978-0-7167-7108-1.

29. Grigor, J.J.; Schmid, M.S.; Fortier, L. Growth and Reproduction of the Chaetognaths Eukrohnia hamata and Parasagitta elegans in the Canadian Arctic Ocean: Capital Breeding versus Income Breeding. J. Plankton Res. 2017, 39, 910-929. [CrossRef]

30. Welch, H.E.; Siferd, T.D.; Bruecker, P. Population Densities, Growth, and Respiration of the Chaetognath Parasagitta elegans in the Canadian High Arctic. Can. J. Fish. Aquat. Sci. 1996, 53, 520-527. [CrossRef]

31. Zo, Z. Breeding and Growth of the Chaetognath Sagitta elegans in Bedford Basin. Limnol. Oceanogr. 1973, 18, 750-756. [CrossRef]

32. Hirst, A.G.; Forster, J. When Growth Models are not Universal: Evidence from Marine Invertebrates. Proc. Royal Soc. B 2013, 280, 20131546. [CrossRef] [PubMed]

33. Binohlan, C.; Pauly, D. The POPGROWTH Table. In FishBase 2000 Concepts, Design and Data Sources; Froese, R., Pauly, D., Eds.; ICLARM: Los Baños, Philippines, 2000; pp. 138-145.

34. De Jager, S.; Dekkers, W.J. Relations Between Gill Structure and Activity in Fish. Neth. J. Zool. 1974, 25, 276-308. [CrossRef]

35. Pauly, D. A Mechanism for the Juvenile-to-Adult Transition in Fishes. ICES J. Mar. Sci. 1984, 41, 280-284. [CrossRef]

36. Meyer, K.A.; Schill, D.J. The Gill-Oxygen Limitation Theory and Size at Maturity/Maximum Size Relationships for Salmonid Populations Occupying Flowing Waters. J. Fish Biol. 2020. [CrossRef]

37. Slabber, M. Natuurkundige Verlustigingen, Behelzende Microscopise Waarneemingen Van de in-En Uitlandse Water-En Land-Dieren; J. Bosch: Haarlem, The Netherlands, 1778. (In Dutch)

38. Van der Hoeven, J. Eenige Aanteekeningen over Martinus Slabber's Natuurkundige Verlustigingen; Benevens Opgave Der Systematische Namen van de Daarin Afgebeelde Diersoorten. Versl. Meded. Kon. Akad. Wet. 1862, 14, 270-285. (In Dutch)

39. Van Benthem Jutting, W.S.S. Martinus Slabber (1740-1835): Amateur-zoöloog in Zeeland. Tijdschriftenbank Zeeland 1970, 1970, 45-66. (In Dutch)

40. Welter-Schultes, F. Reference Summary for Slabber, M. 1769-1778. 12 September 2011. Available online: http:/ /www.animalbase. uni-goettingen.de/zooweb/servlet/AnimalBase/home/reference?id=5303 (accessed on 10 October 2021).

41. Peijnenburg, K.T.C.A.; Pierrot-Bults, A.C. Quantitative Morphological Variation in Sagitta setosa Müller, 1847 (Chaetognatha) and Two Closely Related Taxa. Contrib. Zool. 2004, 73, 305-315. [CrossRef]

42. De Blainville, H.-M.D. Manuel de Malacologie et de Conchyliologie; F.G. Levrault, Edit.: Paris, France, 1825; pp. 1-668. (In French) [CrossRef]

43. Eydoux, F.; Souleyet, M. Vers. In Voyage autour du Monde Exécuté pendant les Années 1836 et 1837 sur la Corvette "La Bonite"; Bertrand, A., Ed.; A. Bertrand: Paris, France, 1852; Volume 2, pp. 645-657. (In French)

44. De Blainville, H.-M.D. [Accounts for] Sagitta, Flèche; Sagitella, Sagitelle. In Dictionnaire des Sciences Naturelles; Levrault, F.G., Ed.; Le Normant: Strasbourg, France, 1827; Volume T.47, pp. 4-8. (In French)

45. Quoy, J.R.C.; Gaimard, J.P. Observations Zoologiques Faites à Bord de l'Astrolabe, en Mai 1826, dans le Détroit de Gibraltar (suite et fin). Description des genres Biphore, Carinaire, Hyale, Flèche, Cléodore, Anatife et Briarée. Ann. Sci. Nat. 1827, 10, 225-239. (In French)

46. Keynes, R.D. (Ed.) Charles Darwin's Zoology Notes E Specimen Lists from H.M.S. Beagle; Cambridge University Press: Cambridge, UK, 2000; ISBN 978-0-521-46569-4.

47. D'Orbigny, A.D. Mollusques. In Voyage dans l'Amérique Méridionale; Bertrand: Paris, France, 1836; Volume 5, pp. 1-758. (In French)

48. Forbes, E. On the Addition of the Order Nucleobracha to the British Molluscous Fauna. In Report of the 13th meeting British Association for the Advancement of Science held at Cork in August 1943. Notices and Abstracts of Miscellaneous Communications to the Sections; John Murray: London, UK, 1844; pp. 72-73.

49. Charles Darwin's Notebooks, 1836-1844: Geology, Transmutation of Species, Metaphysical Enquiries; Barrett, P.H.; Gautrey, P.J.; Herbert, S.; Kohn, D.; Smith, S. (Eds.) British Museum (Natural History): London, UK; Cornell University Press: Ithaca, NY, USA, 1987.

50. Leuckart, R. Bericht Über die Leistungen in der Naturgeschichte der Niederen Thiere Während des Jahres 1848-1853. Arch. Naturgesch. 1854, 20, 289-473. (In German)

51. Leuckart, R. Nachträge und Berichtigungen zu dem ersten Bande von J. van Der Hoeven's Handbuch der Zoologie. Eine Systematisch Geordnete Übersicht der Hauptsächlichste Neueren Leistungen:über die Zoologie der Wirbellosen Thiere; L. Voss: Leipzig, Germany, 1856. (In German) [CrossRef]

52. Hertwig, O. Die Chaetognathen: Ihre Anatomie, Systematik und Entwicklungsgechichte: Eine Monographie. In Studien zur Blättertheorie; G. Fischer: Jena, Germany, 1880. (In German)

53. Gegenbaur, C. Grundzüge der Vergleichenden Anatomie; Wilhelm Engelmann: Leipzig, Germany, 1859. (In German) [CrossRef]

54. Harting, P. Wormen. In Leerboek van de Grondbeginselen der Dierkunde in Haren Geheelen Omvang: Derde Deel Ongewervelde Dieren; H.C.A. Campagne: Tiel, The Netherlands, 1871; pp. 489-796. (In Dutch)

55. Grassi, B.J. I Chetognati. Anatomia e Sistematica con Aggiunte Embriologiche. Fauna und Flora des Golfes von Neapel, 5, Monographie: Die Chaetognathen; W. Engelmann: Leipzig, Germany, 1883; pp. 1-172. (In Italian)

56. Marlétaz, F.; Martin, E.; Perez, Y.; Papillon, D.; Caubit, X.; Lowe, C.; Freeman, R.; Fasano, L.; Dossat, C.; Wincker, P.; et al. Chaetognath Phylogenomics: A Protostome with Deuterostome-like Development. Curr. Biol. 2006, 16, R577-R578. [CrossRef] [PubMed]

57. Matus, D.Q.; Copley, R.R.; Dunn, C.W.; Hejnol, A.; Eccleston, H.; Halanych, K.M.; Martindale, M.Q.; Telford, M.J. Broad Taxon and Gene Sampling Indicate that Chaetognaths are Protostomes. Curr. Biol. 2006, 16, R575-R576. [CrossRef] 
58. Marlétaz, F.; Peijnenburg, K.T.C.A.; Goto, T.; Satoh, N.; Rokhsar, D.S. A New Spiralian Phylogeny Places the Enigmatic Arrow Worms among Gnathiferans. Curr. Biol. 2019, 29, 312-318.e3. [CrossRef]

59. Barthélémy, R.-M.; Casanova, J.-P. Progress in the Knowledge of the Phylogeny of the Chaetognatha Needs Both Molecular Biology and Zoology. Int. J. Fauna Biol. Stud. 2019, 6, 21-26.

60. Ritter-Záhony, R. Revision der Chätognathen. In Deutsche Südpolar-Expedition, 1901-1903, im Auftrage des Reichsamtes des Innern; von Drygalski, E., Ed.; Georg Reimer: Berlin, Germany, 1911; pp. 1-72.

61. Tokioka, T. The Taxonomical Outline of Chaetognaths. Publ. Seto Mar. Biol. Lab. 1965, 12, 335-357. [CrossRef]

62. Vinther, J.; Parry, L.A. Bilateral Jaw Elements in Amiskwia sagittiformis Bridge the Morphological Gap between Gnathiferans and Chaetognaths. Curr. Biol. 2019, 29, 881-888.e1. [CrossRef] [PubMed]

63. Caron, J.-B.; Cheung, B. Amiskwia is a Large Cambrian Gnathiferan with Complex Gnathostomulid-like Jaws. Commun. Biol. 2019, 2, 1-9. [CrossRef] [PubMed]

64. Bieri, R. Six New Genera in the Chaetognath Family Sagittidae. Gulf Caribb. Res. 1991, 8, 221-225. [CrossRef]

65. Bieri, R. Systematics of the Chaetognatha. In The Biology of Chaetognaths; Bone, Q., Kapp, H., Pierrot-Bults, A.C., Eds.; Oxford University Press: Oxford, UK, 1991; pp. 122-136. ISBN 978-0-19-857715-7.

66. Briggs, D.E.G.; Caron, J.-B. A Large Cambrian Chaetognath with Supernumerary Grasping Spines. Curr. Biol. 2017, 27, 2536-2543.e1. [CrossRef]

67. Shu, D.; Conway Morris, S.; Han, J.; Hoyal Cuthill, J.F.; Zhang, Z.; Cheng, M.; Huang, H. Multi-Jawed Chaetognaths from the Chengjiang Lagerstätte (Cambrian, Series 2, Stage 3) of Yunnan, China. Palaeontology 2017, 60, 763-772. [CrossRef]

68. Gasmi, S.; Nève, G.; Pech, N.; Tekaya, S.; Gilles, A.; Perez, Y. Evolutionary History of Chaetognatha Inferred from Molecular and Morphological Data: A Case Study for Body Plan Simplification. Front. Zool. 2014, 11, 84. [CrossRef]

69. Xiao, Y.C. Phylum Chaetognatha (Leuckart, 1894). In Checklist of Marine Biota of China Seas; Liu, R., Ed.; Science Press: Beijing, China, 2008; pp. 842-845. (In Chinese)

70. Michael, E.L. Report on the Chaetognatha Collected by the United States Fisheries Steamer "Albatross" during the Philippine Expedition, 1907-1910; United States National Museum: Washington, DC, USA, 1919. (In Chinese)

71. Hsu, F. On Some Species of Sagitta of China. Sinensia 1943, 14, 120-139. (In Chinese)

72. Sproston, N.G. A preliminary survey of the plankton of the Chu-San region, with a review of the relevant literature. Sinensia 1949, 20, 58-161. (In Chinese)

73. Xu, Z.L.; Dai, Y.F.; Chen, X.Q. Study on Species Composition and Diversity of Chaetognatha in the East China Sea. J. Shanghai Fish. Univ. 2004, 13, 304-309. (In Chinese)

74. Wang, Y.L.; Yuan, Q. Ecological Study on Chaetognatha in the East China Sea. I. Species Composition and Quantity Distribution. Mar. Fish. 2004, 26, 29-34. (In Chinese)

75. Dai, Y.Y. A study on the Species Diversity of Chaetognaths in China Seas. Chin. Biodivers. 1995, 3, 69-73. (In Chinese)

76. Dai, Y. Study on the Ecological Characters of Chaetognatha in Waters of Southern Huanghai Sea and East China Sea I. The Characteristics of Quantitative Distribution. Acta Oceanol. Sin. 2006, 28, 106-111. (In Chinese)

77. Jiang, W.; Wang, Y.L.; Xu, Z.L. Studies on Distribution of Chaetognatha in Taiwan Strait. J. Oceanol. Taiwan Strait 2003, 22, 150-154. (In Chinese)

78. Zhang, G.X.; Yi, J.Q. Diurnal Vertical Migration of Chaetognatha around Nansha Islands Waters Southern South China Sea. J. Trop. Oceanogr. 1995, 24, 49-56. (In Chinese)

79. Du, F.Y.; Li, C.H.; Jia, X.P. A Preliminary Analysis of Chaetognatha Species Groups in Beibu Bay. J. Fish. China 2005, 29, 43-47. (In Chinese)

80. Dai, Y.; Lin, M. Study on the Ecological Characters of Chaetognatha in Waters of Southern Huanghai Sea and East China Sea II. Community Characteristics. Acta Oceanol. Sin. 2007, 29, 90-97. (In Chinese)

81. Xu, Z.L.; Dai, Y.F.; Chen, Y.Q. Relationship between Chaetognatha Abundance and Environmental Factors in the East China Sea. J. Shanghai Fish. Univ. 2004, 13, 203-208. (In Chinese)

82. Xu, Z.L.; Chen, X.Q. Relationships between Dominant Species of Chaetognatha and Environmental Factors in the East China Sea. J. Fish. Sci. China 2005, 12, 76-82. (In Chinese)

83. Liu, Q.; Qu, H.; Zhang, S.; Wei, J. Experimental Study on the Feeding Ecology of Sagitta crassa. J. Fish. China 2006, 30, 767-772. (In Chinese)

84. Liu, Q.; Qu, H.; Zhang, S. Preliminary Studies on the Tolerance to Temperature and Salinity in Sagitta crassa. Trans. Oceanol. Limnol. 2007, 1, 111-116. (In Chinese)

85. Liu, Q.; Zhu, H.Y.; Liu, F.; Ding, Z.Y. Effects of Temperature and Salinity on Oxygen Consumption Rate and Asphyxiation Point of Sagitta crassa. Chin. J. Appl. Ecol. 2011, 22, 3081-3086. (In Chinese)

86. Huo, Y.Z.; Sun, S.; Yang, B. Life Cycle of the Chaetognath Sagitta crassa in the Southern Yellow Sea, China. Oceanol. Limnol. Sin. 2010, 41, 181-185. (In Chinese)

87. Lindsey, C.C. Body Sizes of Poikilotherm Vertebrates at Different Latitudes. Evolution 1966, 20, 456-465. (In Chinese) [CrossRef]

88. Fisher, J.A.D.; Frank, K.T.; Leggett, W.C. Global Variation in Marine Fish Body Size and its Role in Biodiversity-Ecosystem Functioning. Mar. Ecol. Prog. Ser. 2010, 405, 1-13. [CrossRef]

89. McLaren, I.A. Adaptive Significance of Large Size and Long Life of the Chaetognath Sagitta elegans in the Arctic. Ecology 1966, 47, 852-855. [CrossRef] 
90. Reeve, M.R.; Walter, M.A. Conditions of Culture, Food-Size Selection, and the Effects of Temperature and Salinity on Growth Rate and Generation Time in Sagitta hispida Conant. J. Exp. Mar. Biol. Ecol. 1972, 9, 191-200. [CrossRef]

91. Reeve, M.R.; Baker, L.D. Production of Two Planktonic Carnivores (Chaetognath and Ctenophore) in South Florida Inshore Waters. Fish. Bull. 1975, 73, 238-248.

92. Pearre, S. Feeding by Chaetognatha: Energy Balance and Importance of Various Components of the Diet of Sagitta Elegans. Mar. Ecol. Prog. Ser. 1981, 5, 45-54. [CrossRef]

93. Harrison, R.J. Phosphorus and Iron in Sagitta setosa and Sagitta elegans. J. Mar. Biolog. Assoc. 1940, 24, 125-128. [CrossRef]

94. Feng, Q.Y. The Study of Size-Biomass Relationships of Dominant Species of Yellow Sea and East China Sea through Image Technology. Master's Thesis, Graduate School, Institute of Oceanology, Chinese Academy of Science, Qingdao, China, 2013. (In Chinese).

95. Reeve, M.R.; Raymont, J.E.G.; Raymont, J.K.B. Seasonal Biochemical Composition and Energy Sources of Sagitta hispida. Mar. Biol 1970, 6, 357-364. [CrossRef]

96. Kiørboe, T. Zooplankton Body Composition. Limnol. Oceanogr. 2013, 58, 1843-1850. [CrossRef]

97. Thuesen, E.V.; Childress, J.J. Enzymatic Activities and Metabolic Rates of Pelagic Chaetognaths: Lack of Depth-Related Declines. Limnol. Oceanogr. 1993, 38, 935-948. [CrossRef]

98. Sameoto, D.D. Yearly Respiration Rate and Estimated Energy Budget for Sagitta elegans. J. Fish. Res. Bd. Can. 1972, 29, 987-996. [CrossRef]

99. Kruse, S. Biology of Meso- and Bathypelagic Chaetognaths in the Southern Ocean. Ph.D. Thesis, Universität Bremen, Bremen, Germany, 2009.

100. Palomares, M.L.D.; Pauly, D. The Growth of Jellyfishes. Hydrobiologia 2009, 616, 11-21. [CrossRef]

101. Brey, T.; Müller-Wiegmann, C.; Zittier, Z.M.C.; Hagen, W. Body Composition in Aquatic Organisms-A Global Data Bank of Relationships between Mass, Elemental Composition and Energy Content. J. Sea Res. 2010, 64, 334-340. [CrossRef]

102. Schmidt-Nielsen, K. Animal Physiology: Adaptation and Environment; 5th ed.; Cambridge University Press: Cambridge, UK, 1997; ISBN 978-0-521-57098-5.

103. Russell, F.S. On the Biology of Sagitta I. The Breeding and Growth of Sagitta elegans Verrill in the Plymouth Area, 1930-1931. J. Mar. Biolog. Assoc. U.K. 1932, 18, 131-146. [CrossRef]

104. Schmidt-Rhaesa, A.; Vieler, V. Spadella kappae, a New Small Benthic Chaetognath (Spadellidae) from Roscoff, France. Cah. Biol. Mar. 2018, 59, 257-265. [CrossRef]

105. Schmidt-Rhaesa, A.; Vieler, V. Validation of Spadella kappae Schmidt-Rhaesa \& Vieler, a Small Benthic Chaetognath from Roscoff, France. Zootaxa 2020, 4759, 300. [CrossRef]

106. Sverdrup, H.U.; Johnson, M.W.; Fleming, R.H. The Oceans: Their Physics, Chemistry and General Biology; Prentice Hall: New York, NY, USA, 1942.

107. Audzijonyte, A.; Barneche, D.R.; Baudron, A.R.; Belmaker, J.; Clark, T.D.; Marshall, C.T.; Morrongiello, J.R.; van Rijn, I. Is Oxygen Limitation in Warming Waters a Valid Mechanism to Explain Decreased Body Sizes in Aquatic Ectotherms? Glob. Ecol. Biogeogr. 2019, 28, 64-77. [CrossRef]

108. Pearre, S. Growth and reproduction. In The Biology of Chaetognaths; Bone, Q., Kapp, H., Pierrot-Bults, A.C., Eds.; Oxford University Press: Oxford, UK, 1991; pp. 61-75. ISBN 978-0-19-857715-7.

109. Russell, F.S. On the Biology of Sagitta. II. The Breeding and Growth of Sagitta Setosa J. Müller in the Plymouth Area, 1930-1931, with a Comparison with That of S. elegans Verrill. J. Mar. Biolog. Assoc. U.K. 1932, 18, 147-160. [CrossRef]

110. Murakami, A. Rearing Experiments of a Chaetognath, Sagitta crassa. Inf. Bull. Planktol. Jpn. 1966, 13, 62-65. (In Japanese)

111. Nagasawa, S.; Marumo, R. Seasonal Variation in Composition and Number of Epipelagic Chaetognaths in Sagami Bay, Japan. La Mer 1977, 15, 185-195. (In Japanese)

112. David, P.M. The Distribution of Sagitta gazellae Ritter-Záhony. Discov. Rep. 1955, 27, 235-278.

113. Kotori, M. The Biology of Chaetognatha in the Bering Sea and the Northern North Pacific Ocean, with Emphasis on Sagitta elegans. Mem. Fac. Fish. Hokkaido Univ. 1976, 23, 95-183.

114. Kruse, S.; Hagen, W.; Bathmann, U. Feeding Ecology and Energetics of the Antarctic Chaetognaths Eukrohnia hamata, E. bathypelagica and E. bathyantarctica. Mar. Biol. 2010, 157, 2289-2302. [CrossRef]

115. Bone, Q.; Kapp, H.; Pierrot-Bults, A.C. (Eds.) The Biology of Chaetognaths; Oxford University Press: Oxford, UK, 1991; ISBN 978-0-19857715-7.

116. Parry, D.A. Structure and Function of the Gut in Spadella cephaloptera and Sagitta setosa. J. Mar. Biolog. Assoc. U.K. 1944, 26, 16-36. [CrossRef]

117. Bleich, S.; Müller, C.H.G.; Graf, G.; Hanke, W. Flow Generation by the Corona Ciliata in Chaetognatha-Quantification and Implications for Current Functional Hypotheses. Zoology 2017, 125, 79-86. [CrossRef] [PubMed]

118. Kapp, H. Morphology and anatomy. In The Biology of Chaetognaths; Bone, Q., Kapp, H., Pierrot-Bults, A.C., Eds.; Oxford University Press: Oxford, UK, 1991; pp. 5-17. ISBN 978-0-19-857715-7.

119. Katsu-Kimura, Y.; Nakaya, F.; Baba, S.A.; Mogami, Y. Substantial Energy Expenditure for Locomotion in Ciliates Verified by Means of Simultaneous Measurement of Oxygen Consumption Rate and Swimming Speed. J. Exp. Biol. 2009, 212, 1819-1824. [CrossRef] [PubMed]

120. Pauly, D.; Cheung, W.W.L. Sound Physiological Knowledge and Principles in Modeling Shrinking of Fishes under Climate Change. Glob. Change Biol. 2017, 24, e15-e26. [CrossRef] [PubMed] 
121. Allen, K.R. Relation Between Production and Biomass. J. Fish. Res. Bd. Can. 1971, 28, 1573-1581. [CrossRef]

122. Pauly, D.; Christensen, V. Ecosystem Models. Chapter 10. In Handbook of Fish Biology and Fisheries; Hart, P., Reynolds, J., Eds.; Blackwell Publishing: Oxford, UK, 2002; Volume 2, pp. 211-227.

123. Colléter, M.; Valls, A.; Guitton, J.; Gascuel, D.; Pauly, D.; Christensen, V. Global Overview of the Applications of the Ecopath with Ecosim Modeling Approach Using the EcoBase Models Repository. Ecol. Model. 2015, 302, 42-53. [CrossRef] 